\title{
In Pursuit of the Functional Definition of a Mind: the Pivotal Role of a Discourse
}

\section{у пошуках функціонального визначення розуму: ключова роль дискурсу}

\author{
Vitalii Shymko \\ Dr. in Psychology, \\ Professor
}

\author{
Віталій Шимко \\ доктор психологічних наук, \\ професор
}

E-mail: shymko@outlook.com orcid.org/0000-0003-4937-6976

\author{
Pereiaslav-Khmelnytskyi \\ Hryhorii Skovoroda State \\ Pedagogical University \\ 30, Sukhomlynskyi Str., \\ Pereiaslav-Khmelnytskyi, \\ Kyiv Reg., Ukraine, 08401
}

ДВНЗ «Переяслав-Хмельниџький державний педагогічний університет імені Григорія

Сковороди»

$\triangle$ вул. Сухомлинського, 30, м. Переяслав-Хмельницький, Київська обл., Україна, 08401

Original manuscript received April 18, 2018

Revised manuscript accepted September 10, 2018

\section{ABSTRACT}

This article is devoted to describing results of conceptualization of the idea of mind at the stage of maturity. Delineated the acquisition by the energy system (mind) of stable morphological characteristics, which associated with such a pivotal formation as the discourse. A qualitative structural and ontological sign of the system transition to this stage is the transformation of the verbal morphology of the mind into a discursive one. The analysis of the poststructuralist understanding of discourse in the context of the dispersion of meanings (Foucault) made it possible to formulate a notion of it as a meaning that is constituted by the relation between the discursive practice and the worldview, regarded as a meta-discourse or aglobaldiscursive formation. 
In consequence of this relationship, a discrete and simultaneous scattering of meanings arises, the procedural side of which is a concrete discourse, and its productive aspect is linked with the creation of a local discursive formation. Based on this view it is proposed a logical formula of discourse, which takes into account the entropy of the language and the entropy of the worldview, as a particular manifestation of the mind entropy. Using this formula and considering the reactive nature of discourse, it was developed a classification, which included such types of discourses as reactive, suggestive, synthetic and creative. In turn, the proposed types of discourses are correlated with the specific characteristics of certain activities, as a psychological category. Also, it was considered the translation of the structure of discourse dissipation from the cognitive plan into the affective sphere because of which it is formed a hierarchy of significances, which performs the sense-forming function. It was analyzed the inverse influence of the hierarchy of significances on the structure of meanings dispersion and for respective account it was introduced a conditional coefficient of the value deviation of the significance of the meanings. This parameter reflects the sense correction of the meaning that occurs in the process of the emergence of discourse from discursive practice. Thus, the discourse is presented as a complex dynamic formation of the mind arising at the maturity stage of the system as a result of the combined effect of entropic dispersion of meanings and the value deviation of their significances.

Key words: mind, discourse, discursive practice, discursive formation, system, structural ontology, meaning, dispersion of meanings, hierarchy of significances, sense.

\section{Introduction}

This article continues the presentation of the conceptualization of the concept of mind, the introductory provisions of which were published earlier (Shymko, 2018). We recall that the purpose of this theoretical analysis is development of systematic methodological discourse that can be used for the formulation of a functional definition of the mind, considered as an object of interdisciplinary research in the field of Natural Language Processing (NLP).

The synthesis of any scientific definition presupposes the solution of two problems, which are localization of the ontological boundaries of the object being determined (explored) and the description of its known and/or assumed characteristics, which reflect composition, structure and functionality of its components, genesis, interrelations with other objects, etc. In the field of humanitarian knowledge, the formulation 
of definitions is mainly carried out by verbal means. Mechanisms of quantification of natural language do not allow creating a wide practice on the «mathematization» of definitions. It is impossible to exclude the corresponding role of language in the exact sciences as well. All this causes the validity problem of verbal definitions, the evidence of which is actualized when translating texts into different languages. At the same time, the unification of the scientific language also cannot claim a way of solving this problem, mainly because of such an all-linguistic feature, like negativism of the language.

«Instead of preexisting ideas then, we find in the foregoing examples values emanating from the system. When they are said to correspond to concepts, it is understood that the concepts are purely differential and defined not by their positive content but negatively by their relations with other terms of the system. Their most precise characteristic is in being what the others are not» (Saussure, 1959: 117).

Saussure believed that the only exception is the relationship between the signifier and the signified, a positive relationship between them, however, is arbitrary. The relationship does not have neither meaning, nor significance (Saussure, 1959: 120). The idea of language negativism is developed by Lacan, arguing that the signifier does not have a fixed meaning: «No meaning is sustained by anything other than reference to another meaning... Should we try to grasp in the realm of language the constitution of the object, how can we help but notice that the object is to be found only at the level of concept, a very different thing from a simple nominative» (Lacan, 1966: 116).

This peculiarity of the language causes special methodological requirements for verbal definitions, the production of which, in our opinion, should be interpreted less as the descriptive formulation of narratives, and more as synthesis of meanings and the construction of conceptualizations. Continuing the logic of Lacan, if the nature of the language limits the possibility of presentation of meaning through the nominative, then it is necessary to work with available definitive validity of the concept.

\section{Techniques and methodologies of research}

For these purposes, we use the method of structural-ontological analysis of the subject field of interdisciplinary research (Shymko, 2016, 2018b). This method assumes a special procedure for constructing 
visualizations - structural-ontological matrices that reflect the main components of the system description of the studied object. Structuralontological analysis of the object of investigation makes it possible to extract a subject of research from it, and, thus, to concretize the answer to the methodological question «WHAT is being investigated?». Thus, the method provides for the localization of ontological boundaries, separation of the primary process and the material of the system under study. The method allows schematizing the logic of transformation of the material of the system by the primary process and, therefore, describing the morphology of the system. Matrices provide visibility of structural and functional features and interactions of system components, as well as its relationship to a higher order system (supersystem). Finally, the construction of a successive series of matrices allows conceptualizing the notion of the staged, transformational, and other features of the genesis of the system under study. This helps to solve the methodological task related to the question «HOW to investigate?».

The main advantages of the tool we use are, firstly, the simplicity of planning and the orderly implementation of the various stages of systemic methodological analysis, as well as the visibility of its results. Secondly, the synthesized structural-ontological matrices, according to our design, are intended to compensate for language restrictions related to the slip of meanings in the «chain of signifiers» (Lacan, 1966). We believe that the matrices allow productively interfering in, mainly, the syntactic logic of the Lacan's chain of signifiers and endow it with the properties of wanted signifier, or in our terms-the definable (researchable) concept. In this sense, the method of structural-ontological analysis can be conditionally regarded as a quasi-instrument for the logical quantification of the language of scientific definitions.

\section{Results and discussions}

In the previous publication the appropriate place and role of the mind were determined, and the primary process and material of the system were localized, structural-functional connections were described using the structural-ontological analysis of the supersystem. The mind is conceptualized as an energy process unfolding in a space-temporal environment (chronotope) and accompanied by archetypal structuring of neural impulses into images. The genesis of the system at the initial stage, which we conditionally designated as the stage of development 
is considered. In this case, the primary process is concretized with the help of hetero- and homeostatic dichotomy, and also the most significant features of the consistent transformation of the material of the system and its ascent to verbal morphology are described (Shymko, 2018).

The continuation of this analysis necessitates the structuralontological consideration of the mind at the stage of maturity (Figure 1). To be more precise, in this case the term «maturity» is used for qualitative characterization of the system. The connection of this term with the concepts of age, personal, social, professional maturity is conditional and vicarious. So, the stage of maturity presupposes a certain phase of the transformational development of the system, which marks the acquisition by the mind of stable morphological and functional features. What are these features?

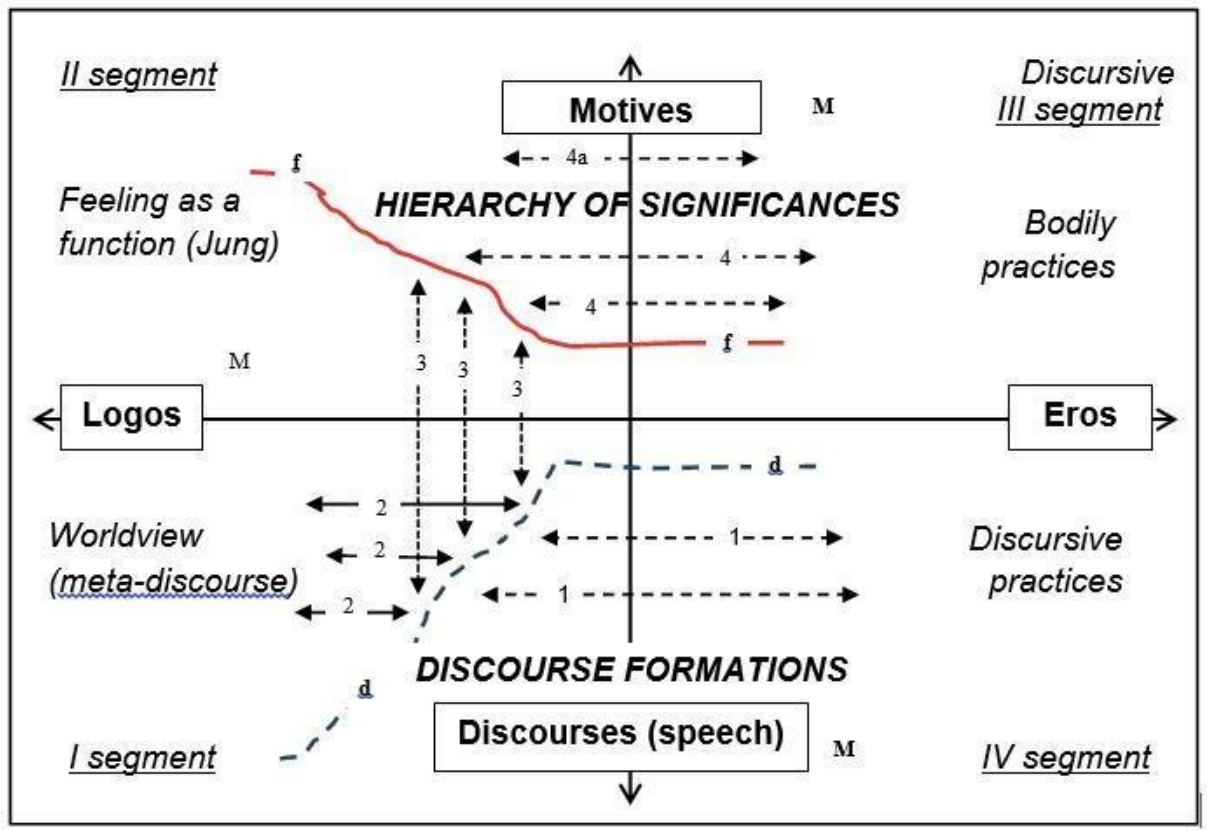

Fig. 1. Structural-ontological matrix of the system. Stage of maturity

The primary process at this stage is represented by the dichotomy of those factors that correspond to the Jungian concepts of Logos and Eros. The heterostasis of the system at the mature stage is represented by the property of distinguishing opposites, i.e. discriminative function of the mind. «There is no consciousness without discrimination of 
opposites. This is the paternal principle, the Logos, which eternally struggles to extricate itself from the primal warmth and primal darkness of the maternal womb; in a word, from unconsciousness» (Jung, 1969a: par. 178). The homeostasis of the mind is represented by the characteristics of binding and withholding, which Jung considered as woman's attributes: "Woman's consciousness is characterized more by the connective quality of Eros than by the discrimination and cognition associated with Logos. In men, Eros ... is usually less developed than Logos. In women, on the other hand, Eros is an expression of their true nature, while their Logos is often only a regrettable accident» (Jung, 1969b: par. 29).

Without sharing the gender categoricity in the cited maitre quotes, we emphasize that Logos and Eros are dichotomous aspects of a single energy whole - the primary process of the system we are studying. The mind cannot exist not only without Logos, but also without Eros. Any act of consciousness (we recall that in this and the previous publication mind, consciousness and intellect, are considered as synonymous concepts) requires both the discrimination of opposites, and the fixation, the holding of what was differentiated. Moreover, as we argue further in the text (when considering discourse practices), it would seem that the «masculine» process of constructing reasoning, first of all, relies on Eros. And such «feminine» phenomena as feelings have the generic characteristics of the Logos and are subject to entropy. The mind is an integral formation, a complex interweaving of both said factors. Let us continue our consideration of their transforming interaction with the material of the system, which is represented by the dichotomy motive discourse.

How exactly has this idea been formed about the primary process and the material of the system at the mature stage? According to the structural-ontological method, the analysis of the system is carried out by visualizing the primary process and the material represented by the dichotomies of the inherent properties. Herewith, the development of the system is reflected in the concretizing refinements of the indicated dichotomies at different stages of genesis. These refinements are realized by means of a logical analysis of the corresponding configuration of factors at the previous (initial) stage of system development. These factors, in addition to the primary process and the material, include morphology, composite-structural and structural-functional characteristics 
of the system. We separately note that the logic of refinement is based on such a concept of the development of the mind, which is characterized by the differentiation of its functions (Jung, 1923; Leontev, 1978; Shchedrovitsky, 1995; Vygotsky, 1978; Witkin, 1974 etc.).

Thus, at the previous stage, the primary process was represented by the dichotomy «heterostasis - homeostasis» (Shymko, 2018a: 335), which is transformed into a functional pair of «Logos - Eros». The fundamental properties of the system are differentiated into the operational functions of the mind, described above using Jungian concepts. The logic of the genesis connection here, in our view, is obvious and does not require any additional reasoning. In turn, a similar development of the material of the system is realized from «needs - word» (Shymko, 2018a: 336) to «motives - discourses». And if the connection between motives and needs is explained by the objectification of the latter (Leontev, 1978), the logic of movement from words to discourses requires a separate commentary.

First of all, the concept word is used by us as a formal unit of speech, as a psychological category, the ontological characteristic of which is related to the meaning (Shymko, 2018a: 336). On the other hand, the speech is realized through the two-component cognitive structure proposed by Saussure (1959): signifier («a segment of mental sound») and signified (concept-image). However, Saussure defines in this way not a verbal, but linguistic unit - a sign. As a result, a terminological ambiguity that does not allow us to clearly recognize the structural and ontological differences that are fundamental for us and the interrelations between speech and language arises. In our opinion, the Saussure's definition of the sign contains more psychological than a linguistic accent. It is noteworthy that Saussure formulates, in fact, the psycholinguistic concept of the sign several decades before the advent of psycholinguistics, ahead in this the scientific thought of his time. So, in this article, speaking about signs, words, statements, we appeal, first of all, to the ir meaning.

Secondly, no less terminological deliquescence is associated with the notion of discourse, which remains at the center of the methodological polemics of philosophers, historians, sociologists, linguists, psychologists, culturologists, and others. We form an idea of discourse basing on the views of the French epistemologist - poststructuralist Michel Foucault: «...discourse is constituted by a group of 
sequences of signs, in so far as they are statements, that is, in so far as they can be assigned particular modalities of existence... The term discourse can be defined as the group of statements that belong to a single system of <discursive> formation; thus I shall be able to speak of clinical discourse, economic discourse, the discourse of natural history, psychiatric discourse» (Foucault, 1972: 107-108).

However, Foucault believes that a discursive formation is formed centrifugally, according to the principle of dispersion: «Paradoxically, to define a group of statements in terms of its individuality would be to define the dispersion of these objects, to grasp all the interstices that separate them, to measure the distances that reign between them - in other words, to formulate their law of division» (Foucault, 1972: 33). In turn, this causes the features of the analysis of the discursive formation by Foucault: «Instead of reconstituting chains of inference (as one often does in the history of the sciences or of philosophy), instead of drawing up tables of differences (as the linguists do), it would describe systems of dispersion. Whenever one can describe, between a number of statements, such a system of dispersion, whenever, between objects, types of statement, concepts, or thematic choices, one can define a regularity (an order, correlations, positions and functionings, transformations), we will say, for the sake of convenience, that we are dealing with a discursive formation - thus avoiding words that are already overladen with conditions and consequences, and in any case inadequate to the task of designating such a dispersion, such as 'science', 'ideology', 'theory', or 'domain of objectivity'» (Foucault, 1972: 37-38).

As we can see, Foucault defines discourse through the «sequence of signs», and the «system of dispersion», which reflects such characteristics of discourse as - sequence and entropy, respectively. Since we consider a linguistic sign with a psycholinguistic emphasis on meaning (see above), we suggest understanding the discourse as a meaning, generated by the entropy of a sequence of other meanings with a specific structure of their dispersion (dissemination, dissipation, scattering). Thus, the discourse is the meaning of the dispersion of meanings.

We agree with Foucault regarding discreteness and simultaneity of discourse: «Discourse must not be referred to the distant presence of the origin, but treated as and when it occurs» (Foucault, 1972: 25; italics is mine, V. Sh.). However, in the system description the discourse cannot be considered arbitrarily, i.e. outside the ontology of the 
mind. The structure of the dispersion of meanings, which «launches» discourse, does not possess any objectified meaning per se. We believe that discourse (as meaning) arises as a result of the correspondence (interrelation) of a particular dispersion structure with actualized in the mind other structures of the scattering of meanings. The sedis courses accumulated during previous experience are localized in the worldview (segment 1, Figure 1). In our opinion, the worldview, in fact, is a complex set of discursive formations. In other words, the worldview is a metadiscourse, a global discursive formation. Thus, the discourse is a meaning constituted by the relation between the actual dispersion of meanings and the worldview, as a meta-discourse. The proposed definition, at this stage of our thinking, can be depicted in the form of a logical formula:

$$
D_{m}=\frac{\left(m_{1}+m_{2}+\cdots+m_{n}\right)\left(H_{L} N+H_{M}\right)}{\left(\sum_{n=1}^{m s} D_{M}\right) H_{M}}
$$

Where, $\mathrm{D}_{\mathrm{m}}$ - discourse; $\left(\mathrm{m}_{1}+\mathrm{m}_{2}+\ldots \mathrm{m}_{\mathrm{n}}\right)$ - the sequence of meanings; $\mathrm{N}$ - the number of meanings (signs, words, statements); $\mathrm{H}_{\mathrm{L}}$ - the entropy of the language; $\Sigma \mathrm{D}_{\mathrm{M}}$ - the worldview, as a meta-discourse; $\mathrm{H}_{\mathrm{M}}$ - the entropy of the worldview. The multiplications in the numerator and denominator are the structures of dispersion of discourse meanings and the worldview, respectively.

In the proposed formula, we introduce two coefficients of entropy, thus differentiating dispersion of the discourse and meta-discourse. Dispersion of the latter is determined by the entropy of the mind, as an energy process. Note that we consider the dispersion of the worldview, as a special case of the entropy of the mind. This problem has been of interest to researchers in recent years (Carhart-Harris, 2014; Chen, 2016; Guevara, 2016; Mateos, 2018; Pepperell, 2018; Scrimali, 2008; Tao, 2018 etc.). Dispersion of discourse is determined by the cumulative influence of the entropy of the mind (which realizes the discourse) and the entropy of the language by which the discourse is realized. For example, for English this parameter is 1.3-2.3 bits per letter (Cover \& King, 1978; Shannon, 1951).

The main, most obvious hypotheses-consequences of the above formula is that if the worldview $\left(\Sigma D_{M}=0\right)$ is not formed (unavailable) and/or the mind is an inoperative $\left(\mathrm{H}_{\mathrm{M}}=0\right)$, it makes no sense to speak 
of discourse. Discourse is absent if there is no sequence of meanings $\left(\mathrm{m}_{1}+\mathrm{m}_{2}+\ldots+\mathrm{m}_{\mathrm{n}}=0\right)$ and/or there is no dispersion of meanings $\left(\mathrm{H}_{\mathrm{n}}+\mathrm{H}_{\mathrm{M}}=0\right)$. If $\mathrm{D}_{\mathrm{m}}<1$, the discourse can be considered as potentially adaptive. That is, one that is assimilated by meta-discourse while preserving the architecture of the worldview, as a global discursive formation. If $\mathrm{D}_{\mathrm{m}}>1$, then this discourse is transformational one and has the potential to either qualitatively transform the worldview or cause a maladaptive or reciprocal defensive reaction to discourage discourse. In the latter case, the reactions will be directed to the dysfunction of the sequence of meanings (for example, distortion, substitution or displacement of separate meanings) and/or correction of the structure of their dispersion (for example, by defensive devaluation, intellectualization, moralization) and/or termination of entropy (for example, by distracting the mind's attention from the discourse or its component, refocusing to another discourse). The localization, structure and dynamics of these reactions, as well as other interactions of discourse and meta-discourse, are the subject of a separate system description and are not given in this article in the interests of its brevity.

Verification of the above hypotheses is related to the prospect of developing a method for quantifying discourse as a key component of the problem of NLP, which in turn has been solved within the framework of Artificial General Intelligence research. In our opinion, the most appropriate mathematical instrument for these purposes, still exclusively, is the theory of information entropy (Shannon \& Weaver, 1949; Cover \& Thomas, 2006 etc.). The main difficulty of such quantification, in our opinion, is related not so much to the «sequence of signs» as to the measurement of the «dispersion system» of discourse (Foucault, 1972).

So, considering the nature of the sign, Saussure postulates two principles: the first is on the arbitrariness of the sign; the second is on the linear character of the signifier. According to the second principle: «The signifier, being auditory, is unfolded solely in time from which it gets the following characteristics: (a) it represents a span, and the span is measurable in a single dimension; it is a line. While Principle II is obvious, apparently linguists have always neglected to state it, doubtless because they found it too simple; nevertheless, it is fundamental, and its consequences are incalculable. Its importance equals that of Principle I; the whole mechanism of language depends 
upon it» (Saussure, 1959: 70). Taking this into account, the question arises: how to overcome the linearity of the signifier and describe heterogeneous structure of the discourse dispersion?

To answer this question, we return to our structural-ontological matrix (Fig. 1). Any specifically arising discourse is schematically depicted in its lower half-plane as a dotted line (line d, Fig. 1). The direct part of the dotted line (segment 4, Figure 1) reflects the discourse ontology associated with the extension. Here the discourse is presented as Foucault's «sequence of signs» or, in our terms, a sequence of meanings. This property of discourse is essentially conditioned by the grammar of the language, as an information-sign model of the environment. In this case, the language serves as an instrument in the formation of the verbal morphology of the mind at the stage of development of the system, which we considered in a previous publication (Shymko, 2018a). Further differentiation of the primary process and material of the system at the stage of maturity leads to the transformation of the verbal morphology of the mind into a discursive one. The emergence of discursive morphology is a qualitative sign of the transition of the system to the stage of maturity. The developing mind is practicing the construction of elementary judgments, mastering the vocabulary and assimilating the syntax of the language. The reasoning of the mature mind is realized through discourses, which can be both adopted and self-generated, which we will discuss below. The text (the product of speech activity) produced by the mind at the stage of development is informative; the text of mature mind is cultural. At the stage of maturity, the language ceases to be a sufficient means for constructing an adequate model of the environment, because now the chronotope has not only space-time characteristics, but also a historical and cultural dimension.

Thus, the development of the mind entails first mastering the language as a tool for modeling the environment. Further differentiation of the system involves the acquisition of the ability of the mind to operate in the field of discursive events. «Language is still a system for possible statements, a finite body of rules that authorizes an infinite number of performances. The field of discursive events, on the other hand, is a grouping that is always finite and limited at any moment to the linguistic sequences that have been formulated; they may be innumerable, they may, in sheer size, exceed the capacities of recording, 
memory, or reading: nevertheless they form a finite grouping. The question posed by language analysis of some discursive fact or other is always: according to what rules has a particular statement been made, and consequently according to what rules could other similar statements be made? The description of the events of discourse poses a quite different question: how is it that one particular statement appeared rather than another?» (Foucault, 1972: 27).

Historical and cultural features of the field of discursive events are reflected through the prevalence of certain discursive practices, in turn, organized in accordance with specific rules (Foucault, 1972: 46). The function of these rules with respect to the discursive field, in our view, is similar to the role of the grammar of the language in relation to speech. Therefore, the corresponding structural-ontological part of the system (segment 4, Figure 1) in our analysis is represented by discursive practices, and not by the field of events. In continuation of the thesis about the inevitability of the language ontology (Shymko, 2018a), we consider that the verbal morphology of the mind naturally acquires a discursive organization at the mature stage of the system. Discursive practices, like language, are initially localized «outside» and «adopted» (internalized) by the mind, as an instrument of reasoning and a means of organizing the worldview. To be more precise, reasoning not only has a discursive organization but, in fact, is identical with discourse. By analogy with the semiotic readiness of the mind for language, we consider it appropriate to assume the existence of a discursive readiness, the nature and features of which are related to the entropy of the mind as an energy process.

According to the logical formula above, a discursively organized worldview (meta-discourse) responds to discursive practice, resulting in a reactive discourse. The absence of such a reaction characterizes the uncritical acceptance of discourse, which is possible in the whole spectrum of various situations that we combine into a category of suggestive discourse. Discourse, which is not initiated by discursive practice from the outside, but arises from activities in the meta-discourse, we indicate as a synthetic discourse. At the same time, we clarify that the absence in this and other examples of an external source of discursive practice does not eliminate the reactive element of the discourse being generated. Discourse can arise as a result of a dialogue with an internalized object or «soul searching'. Here it is appropriate to 
mention Lacan's argument about the place and role in the discourse of «the other» factor (Lacan, 1966). Reactivity is an inalienable feature of discourse, conditioned by an aprioristic primacy of discursive practice. The mind appears in a world in which the language ALREADY exists. The mind possesses of speech in the information space, which is ALREADY structured by discursive practices. However, the newly generated discourse can discover a unique structure for the dispersion of meanings, which is not identical with the discursive practices available to the particular mind and the corresponding contents of his meta-discourse. Such a discourse we categorize as exclusive or creative.

The proposed typification of discourses is interrelated with the specific characteristics of activity, as a psychological category. Thus, the dominance of reactive and suggestive discourse is inherent in different types of performing activity or activity under instructions. Synthetic discourse is relevant to complex activities where norms are present at the conceptual (strategic) level and presuppose certain autonomy of the mind at intermediate (tactical) stages of the activity. That is to say, synthetic discourse is associated with performing activities that require creativity and ingenuity. However, true creativity involves going beyond existing standards and therefore involves an exclusive discourse. Creative activity marks the debut of a unique discursive practice, the subsequent translation of which again determines the performing activities.

Separately, we note that discourse practice is not something like a «concentrated» discourse, since its ontology (segment 4, Figure 1) is characterized by the presence of a length and the absence of dispersion, with the exception of the entropy of the language. In fact, discursive practice is an information code or a discourse-initiating text. The key ontological characteristic of a discourse is the dispersion of meanings associated with the entropy of the worldview, as a particular case of the entropy of the mind. It is noteworthy that therefore the worldview cannot be reduced to a static data container, reduced only to some organized repository or, in other words, to memory. The nature and, as a consequence, the functionality of the worldview are entropic. The apparent stability or, at least, the inertia of the worldview is ensured by the repetition of the repertoire of discrete and simultaneous discourses, from which the global discursive formation is woven. Metaphorically speaking, the meta-discourse is not so much a river bed structure as a 
dynamic configuration of the kinetic energy vectors of the water mass moving here and now along a particular channel.

Returning to the question of overcoming the linearity of the signifier in discourse, it should be noted that the entropy of the mind covers not only the cognitive but also the affective component of the ontology of the mind, represented at the mature stage of the system by the category «feeling» (segment 2, Figure 1). Here we again turned to the Jungian treasury and used the notion of feeling as a rational function of consciousness or as a method of constructing judgments on an axiological basis, i.e. through value experiencing. Jung claims that along with the «logic of thinking» it is appropriate to talk about the «logic of feelings» and that in both cases rational reasoning takes place (Jung, 1971). We recall that in our structural and ontological analysis of the mind, the feeling arises as a result of the differentiation of the affective-dynamic component of the system, which in turn has a neurohumoral etiology (Shymko, 2018a). Thus, seems that the value experiencing paradoxically combines both emotional and rational aspects. This morphological nuance of the system refers us to the structural and dynamic understanding of the experience already mentioned in the previous publication, as a transformational activity aimed at «establishing a semantic correspondence between consciousness and existence»(Vasilyuk, 1991). This understanding actualizes the question of the structural and ontological distinction of phenomena the meaning and the sense, as well as the nature of the linkages between them. We not only believe that discourse is a meaning (see the definitions above), but we also assume that the reverse assertion is true: any meaning has a discursive structural-ontological architecture localized in the lower half-plane of our matrix (segments 1.4, Figure 1). In turn, the meaning is correlated with the significances hierarchy, localized in the upper half-plane (segments 2, 3, Fig. 1). We consider this structure as a sense-forming factor, the interaction of which with discourse will be revealed below.

We note that the Jungian function of thinking would localize in segment 1 and coincide with the curve part of the dotted line on our structural-ontological matrix (line d, Figure 1). Therefore, our idea of discourse corresponds to Jung's notions of the function of thinking however it is not identical to these concepts. Thus, Jung considered feeling and thinking as a pair of dialectically opposing functions with a 
mutually exclusive vector of action. We believe that the feeling correlates with discourse in a complementary way and reflects (translates) the structure of its dispersion through experience. On the other hand, the feeling has a value organization with its own structure of dissipation of values, analogous to the dissemination of meanings in discourse. Given the morphological features of the analyzed system, these values act as significances of meanings. The above-mentioned repetition of the repertoire of discourses, which are part of the structure of the metadiscourse, causes the recurrence of feelings (as value experiences), dispersing the significances in the corresponding hierarchy. Thus, in our structural-ontological matrix, the hierarchy of significances has a distinct etiology from the concept of the hierarchy of values, often used in the scientific literature, as a rule, considered in the context of the needmotivational understanding of activity. Nevertheless, both factors are noted and considered in our thinking, because they are ontologically «adjacent» and interact in terms of conditioning of body activity.

To understand the praxeological aspect of the concept of mind, we consider it necessary to distinguish the influence of the hierarchy of significances and the need-motivational contribution to the linearly unfolding (simultaneously with discourse) series of such psychophysiological states and activities of the corporal mind carrier as bodily practice (segment 3, Figure 1). This distinction has not only research, but also of fundamental applied importance. For example, when interpreting the origin of stress, recorded using so-called «lie detectors». By the way, the wording «lie detection», in our opinion, generates a morally obsolete discourse, the modernized version of which could sound like an assessment of the congruence of discourse.

As noted, we proceed from the reactive nature of discourse. Discursive practice actualizes the relevant content of the meta-discourse (lines 1, Figure 1), which responds by cognitive «perturbation» (lines 2, Figure 1), resulting in the structure of disseminating the meanings of a particular discourse. This structure is translated from the cognitive plan into the affective plan (lines 3, Figure 1), triggering the structure of the scattering of significances (the curve part of the line f, Fig. 1). The latter is reflected linearly (in the sense of time) in bodily practice (lines 4, Figure 1) mingling and interacting with the need-motivational stimulation (line 4a, Fig. 1). The described dynamics of generation and unfolding of discourse forms an integral arc (line M, Figure 1), which 
schematically reflects the ontology of the mind at the mature stage of the functioning of the system. As we can see, discourse plays a pivotal role.

As a final remark, we want to draw attention to the fact that lines with double-sided arrows on our matrix (Figure 1) mean a direct and reverse character of the interaction of the relevant factors. Of particular interest for understanding discourse is the inverse influence of the significance hierarchy on the meanings dispersion structure. To account for this effect, we introduced the conditional angular coefficient of the value deviation of the significance of the meanings - $\phi$. Under the value deviation of significance, we purport such a sense correction of meaning (lines 3, Figure 1), which occurs under the influence of a hierarchy of significances in the process of the emergence of discourse. In other words, when the meaning changes its ontological location, namely, in the «transition» from discursive practice to the actual discourse (lines 1, Figure 1). Thus, at this stage of the structuralontological analysis the logical formula of the discourse acquires the following form:

$$
D_{m}=\frac{\left(m_{1} \phi_{1}+m_{2} \phi_{2}+\cdots+m_{n} \phi_{n}\right)\left(H_{L} N+H_{M}\right)}{\left(\sum_{n=1}^{m} D_{M}\right) H_{M}}
$$

A graphic comment to this formula is Figure 2, on which the connected chain of segments represents discursive practice. The intermittent set of vector segments schematizes the discourse, as a sequence of meanings in time, subject to entropic dispersion and value deviation. If the significance of the meaning coincides with the corresponding characteristic «provided» by the discursive practice, then there is no deviation (angle $=0^{\circ}$, coefficient $\phi=1$ ), as it is depicted in the second interval of the time scale (hereinafter - interval). A noncritical (for the relevance of meanings in the discourse to meanings in discursive practice) the value deviation of significance can be conditionally taken to be acute angles $(0<\phi<1)$, an example of which is depicted in the first interval. With a direct angle $=90^{\circ}$, $\phi=0$, i.e. the value deviation of significance determines the irrelevance of the meaning in relation to practice. The oretically, in this case, it can be assumed either the «fallout» of the meaning from the discourse or its replacement by another (relevant) meaning, or the formation of an alternative discourse. The obtuse angles of deviation will form semantic contradictions as in the third interval $(-1<\phi<0)$, potentially leading 
either to a substantial correction (reprocessing) of discursive practice in the process of discourse unfolding, or to the emergence of a new discourse, or to the cessation of discursive activity. As you can see, deviations of meanings significances can lead not only to correction, but also to the transformation of both separate meanings and discourses.

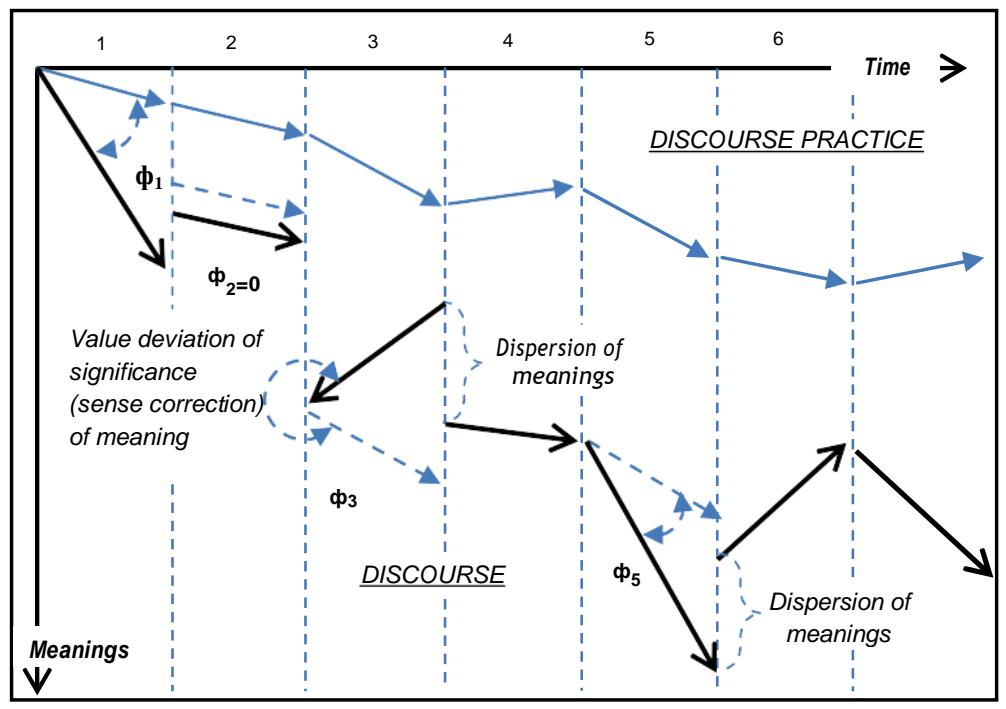

Fig. 2. Schematization of the meanings correction in discourse

The informativeness of the proposed schematization (Figure 2) is also in the fact that the elements of the figure collectively reflect the fundamental structure of the discursive formation, of which Foucault wrote: «A discursive formation is not, therefore, an ideal, continuous, smooth text that runs beneath the multiplicity of contradictions, and resolves them in the calm unity of coherent thought; nor is it the surface in which, in a thousand different aspects, a contradiction is reflected that is always in retreat, but everywhere dominant. It is rather a space of multiple dissensions; a set of different oppositions whose levels and roles must be described» (Foucault, 1972: 155). If the procedural aspect of discourse is represented in the dispersion and deviation of meanings, then its effective aspect is undoubtedly connected with the emergence of a discursive formation: «It is possible to describe several 
distinct emergences of a discursive formation. The moment at which a discursive practice achieves individuality and autonomy, the moment therefore at which a single system for the formation of statements is put into operation, or the moment at which this system is transformed, might be called the threshold of positivity» (Foucault, 1972: 186).

The conditions and regularities of attaining the threshold of positivity are connected not only with the structural and ontological features of mind, that we described at the maturity stage. Beyond this publication, there remains the coverage of a whole layer of issues related to the stabilization of discursive formations, the emergence and functioning of their conglomerations within the framework of a single hierarchical structure that forms a meta-discourse. Of particular interest in this area is the understanding of discursive formations in the context of the Jungian theory of complexes, as a aggregation of emotionally charged ideas (Jung, 1969b). Such understanding, in our opinion, is necessary for studying the conscious and unconscious components of discursive phenomena. A separate careful analysis ought to be devoted to the multidimensionality of the interaction between discourses, discursive practices and formations. Also, in this publication our reflections on the dimension of discourse, the mechanisms and methods of fixation the beginning and end of discourses were not outlined. And, finally, we have not consciously touched upon the category of knowledge in this work, because of the extraordinary capacity and complex integral character of the very problematic of the discursive field of knowledge. Disclosure of this topic requires a detailed exposition of the results of comprehension of specific empirical observations and experiments, which is possible in itself after careful theoretical and methodological analysis. This publicationis an attempt to step in such a direction.

\section{Conclusions}

Summing up the results of conceptualization of the idea of mind at the stage of maturity, we note the acquisition by the system of stable morphological characteristics associated with such a key formation as the discourse. A qualitative structural and ontological sign of the system transition to this stage is the transformation of the verbal morphology of the mind into a discursive one. The analysis of the poststructuralist understanding of discourse in the context of the dispersion of meanings (Foucault) made it possible to formulate a 
notion of it as a meaning that is constituted by the relation between the discursive practice and the worldview, regarded as a meta-discourse or a global discursive formation. In consequence of this relationship, a discrete and simultaneous scattering of meanings arises, the procedural side of which is a concrete discourse, and its productive aspect is linked with the creation of a local discursive formation. Based on this view it is proposed a logical formula of discourse, which takes into account the entropy of the language and the entropy of the worldview, as a particular manifestation of the mind entropy. Using this formula and considering the reactive nature of discourse, it was developed a classification, which included such types of discourses as reactive, suggestive, synthetic and creative. In turn, the proposed types of discourses are correlated with the specific characteristics of certain activities, as a psychological category. Also, it was considered the translation of the structure of dissipation of discourse from the cognitive plan to the affective sphere because of which it is formed a hierarchy of significances, which performs the senseforming function. It was analyzed the inverse influence of the hierarchy of significances on the structure of meanings dispersion and for respective account it was introduced a conditional coefficient of the value deviation of the significance of the meanings. This parameter refl ects the sense correction of the meaning that occurs in the process of the emergence of discourse from discursive practice. Thus, the discourse is presented as a complex dynamic formation of the mind arising at the maturity stage of the system as a result of the combined effect of entropic dispersion of meanings and the value deviation of their significances.

\section{References}

Carhart-Harris, R.L., Leech, R., Hellyer, P.J., Shanahan, M., Feilding, A., Tagliazucchi, E., Chialvo, D.R., \& Nutt, D. (2014). The entropic brain: a theory of conscious states informed by neuroimaging research with psychedelic drugs. Front. Hum. Neurosci, 8(20). doi: 10.3389/fnhum.2014.00020

Chen, J. (2016). The Entropy Theory of Mind. In: The Unity of Science and economics. Springer, New York, NY.

Cover, T., \& King, R. (1978). A convergent gambling estimate of the entropy of English. Information Theory, IEEE Transactions on., 24 (4), 413-421.

Foucault, M. (1972). Archaeology of knowledge and the discourse on language. New York: Pantheon.

Guevara Erra, R., Mateos, D.M., Wennberg, R., Perez, \& Velazquez, J.L. (2016). Statistical mechanics of consciousness: maximization of information content of network is associated with conscious awareness. Phys. Rev. E., 94(052), 402. doi: 10.1103/PhysRevE.94.052402 
Jung, C.G. (1923). Psychological types; or, The psychology of individuation. London : Paul, Trench, Trubner.

Jung, C.G. (1969a). Archetypes and the Collective Unconscious [sic], Collected Works of C.G. Jung (Vol. 9, Part 1), Princeton, N.J. : Princeton University Press.

Jung, C.G. (1969b). Aion: Researches into the Phenomenology of the Self, Collected Works of C.G. Jung (Vol. 9, Part 2), Princeton, N.J. : Princeton University Press.

Jung, C.G. (1971). Psychological Types, Collected Works of C.G. Jung (Vol. 6), Princeton, N.J. : Princeton University Press.

Lacan, J. (1966). The Insistence of the Letter in the Unconscious. Yale French Studies, 36/37, 112-147.

Leontev, A.N. (1978). Activity, Consciousness, and Personality. Prentice-Hall, https:// www.marxists.org/archive/Leontev/works/1978/index.htm

Mateos, D.M., Guevara Erra, R., Wennberg, R., \& Perez Velazquez, J.L. (2018). Measures of entropy and complexity in altered states of consciousness. Cogn Neurodyn., 12 (1), 73-84. doi: 10.1007/s11571-017-9459-8

Pepperell, R. (2018). Consciousness and integrated energy differences in the brain. arXiv:1804.10508

Saussure, F. (1959). Course in general linguistics. New York, Philosophical Library.

Scrimali, T. (2008). Entropy of mind and negative entropy. A cognitive and complex approach to schizophrenia and its therapy. London : Karnac Books.

Shchedrovitsky, G.P. (1995). Selected Works. Moscow, Russia: School of Cultural Politics.

Shannon, C.E., \& Weaver, W. (1949). The Mathematical Theory of Communication. Univ of Illinois Press.

Shannon, C.E. (1951). Prediction and entropy of printed English. Bell Systems Technical Journal, 30, 50-64.

Shymko, V.A. (2016). Systemic localisation of the object in psychological research: structural and ontological visualization. Bulletin of Kiev Taras Shevchenko University, 1 (34), 47-51. http://miljournals.knu.ua/index.php/visnuk/article/ viewFile/19/15 [in Ukrainian].

Shymko, V. (2018a). In Pursuit of the Functional Definition of a Mind: The Inevitability of the Language Ontology. Psycholinguistics, 23(1), 327-346. https://doi.org/10.5281/zenodo.1211593

Shymko, V.A. (2018b). Object field of organizational culture: methodological conceptualization. International Journal of Organizational Analysis, 26, 4.

Tao, Y. (2018). Boltzmann machine with self-referential entropy. Doi:10.13140/ RG.2.2.33014.91203

Vasilyuk, F. (1991). The Psychology of Experiencing. Publisher : Harvester Wheat sheaf.

Vygotsky, L.S. (1978). Mind in society. The development of higher psychological processes. Cambridge, Mass.

Witkin, H.A. (1974). Psychological differentiation. Studies of development. N.Y.

\section{АНОТАЦІЯ}

У статті викладені результати концептуалізації поняття розум на стадії зрілості, за умов якої енергетична система (розум) набуває сталих морфологічних характеристик, пов'язаних з таким 
ключовим утворенням, як дискурс. Якісною структурно-онтологічною ознакою переходу системи на вказану стадію $\epsilon-$ трансформація вербальної морфології розуму в дискурсивну. Проведено аналіз постструктуралістського розуміння дискурсу в руслі розсіювання значень (М. Фуко), що дозволило сформулювати про нього таке уявлення значення, що конституюється відношенням між дискурсивною практикою та світоглядом як мета-дискурсом або глобальною дискурсивною формацією. Внаслідок такого відношення виникає дискретне і симультанне розсіювання значень, процесуальна сторона якого, власне, іє конкретний дискурс, а його результативний аспект пов'язаний з породженням локальної дискурсивної формації. На основі вказаного уявлення запропонована логічна формула дискурсу, що враховує ентропію мови та ентропію картини світу, як окремого прояву ентропії розуму. За допомогою вказаної формули і з урахуванням реактивної природи дискурсу розроблено класифрікацію, до котрої включені такі типи дискурсів - реактивний, сугестивний, синтетичний і творчій. У свою чергу, запропоновані типи дискурсів співвіднесені з специфрічними характеристиками декотрих видів діяльності як психологічної категорії. Також розглянуто трансляцію структури розсіювання дискурсу 3 когнітивного плану в афрективну сфреру, в результаті чого фоорується ієрархія значущостей, яка виконує функцію смислоутворення. Проаналізовано зворотній вплив ієрархії значущостей на структуру розсіювання значень дискурсу та для його врахування введено умовний коефріцієнт ціннісного відхилення значущості значення. Даний параметр враховує смислову корекцію значення, що відбувається в процесі виникнення дискурсу із дискурсивної практики. Таким чином, дискурс представлено як складне динамічне утворення розуму, яке виникає на стадії зрілості системи в результаті сукупної дії ентропічного розсіювання значень та иіннісного відхилення їх значущостей.

Ключові слова: розум; дискурс; дискурсивна практика; дискурсивна формація; система; структурна онтологія, значення; розсіювання значень; ієрархія значущостей; смисл.

\section{Шимко Виталий. В поисках функционального определения разума: ключевая роль дискурса}

\section{АННОТАЦИЯ}

В статье изложены результаты концептуализации понятия разум на стадии зрелости, в условиях которой энергетическая система (разум) обретает устойчивые морфологические характеристики, связанные с таким ключевым образованием, как дискурс. Качественным

(C) Vitalii Shymko 
структурно-онтологическим признаком перехода системы на указанную стадию - является трансформация вербальной морфологии разума в дискурсивную. Проведен анализ постструктуралисткого понимания дискурса в русле рассеивания значений (М. Фуко), что позволило сорормулировать представление о нем, как о - значении, которое конституируется отношением между дискурсивной практикой и мировоззрением, рассматриваемым в качестве мета-дискурса или глобальной дискурсивной формации. В следствии такого отношения возникает дискретное и симультанное рассеивание значений, процессуальная сторона которого, собственно, и есть конкретный дискурс, а его результативный аспект связан с порождением локальной дискурсивной формации. На основе указанного представления предложена логическая фрормула дискурса, учитывающая энтропию языка и энтропию картины мира, как частного проявления энтропии разума. С помощью указанной формулы и с учетом реактивной природы дискурса разработана классификация, в которую вошли такие типы дискурсов, как - реактивный, суггестивный, синтетический и творческий. В свою очередь, предложенные типы дискурсов соотнесены со специфическими характеристиками некоторых видов деятельности, как психологической категории. Также рассмотрена трансляция структуры рассеивания дискурса из когнитивного плана в афрфективную сореру, в результате чего форммиуется иерархия значимостей, выполняющая функцию смыслообразования. Проанализировано обратное влияние иерархии значимостей на структуру рассеивания значений дискурса и для его учета введен условный коэффрициент ценностного отклонения значимости значения. Данный параметр учитывает смысловую коррекцию значения, происходящую в процессе возникновения дискурса из дискурсивной практики. Таким образом, дискурс представлен в качестве сложного динамического образования разума, возникающего на стадии зрелости системы в результате совокупного действия энтропического рассеивания значений и ценностного отклонения их значимостей.

Ключевые слова: разум; дискурс; дискурсивная практика; дискурсивная формация; система; структурная онтология, значение; рассеивание значений; иерархия значимостей; смысл. 